\title{
OPTIMASI PENGEMBANGAN KELEMBAGAAN INDUSTRI PANGAN ORGANIK DI JAWA TIMUR
}

\author{
MOCH. AGUS KRISNO BUDIYANTO \\ Program Studi Pendidikan Biologi FKIP Universitas Muhammadiyah Malang \\ E-mail: aguskrisno@yahoo.co.id
}

\begin{abstract}
ABSTRAK
Penelitian ini dimaksudkan untuk mengindentifikasi optimasi pengembangan kelembagaan industri pangan organik di Jawa Timur. Jenis penelitian yang digunakan dalam penelitian ini adalah penelitian fenomenologi. Subyek penelitian adalah lembaga industri pangan oganik yang terdiri dari UMKM pangan organik, Dinas Pertanian, Industri Pangan, Kelompok Tani Pangan Organik, dan Perbankan di Kabupaten Lumajang, Kabupaten Malang, dan Kabupaten Blitar Provinsi Jawa Timur. Metode pengumpulan data yang digunakan adalah wawancara mendalam dan observasi peran serta. Uji keabsahan data yang digunakan adalah triangulasi sumber dan metode. Data penelitian yang diperoleh dianalisis dengan analisis kualitatif (Content Analysis) dengan menggunakan interaktif model dari Miles dan Huberman.Dari hasil penelitian dapat dinyatakan bahwa optimasi pengembangan kelembagaan pangan organnik di Jawa Timur terbagi ke dalam tiga pola optimasi yaitu pola klaster, pola kemitraan, dan pola BDSP (Business Development Services Provider). Pola klaster merupakan pengembangan kelembagaan industri pangan organik dengan cara pengelompokkan lembaga pangan organik (termasuk UMKM) dalam suatu kawasan atau menetapkan wilayah sebagai kawasan usaha/industri tertentu. Pola kemitraan terdiri dari kemitraan inti plasma dan kemitraan bapak angkat. Pola BDSP merupakan pola pengembangan berbasis pada sistem lembagajasa pengembangan usaha. Secara umum pola klaster mampu meningkatkan kinerja penyediaan, distribusi, pemasaran, dan utilitas industri pangan organik di Jawa Timur. Kabupaten Lumajang merupakan daerah yang paling potensial dalam pengembangan pola klaster industri pangan oganik.
\end{abstract}

Kata kunci: makanan organik, pengembangan kelembagaan, jenis cluster, jenis kemitraan

\begin{abstract}
The objective of this study is to identify optimalization of industries institutional development of organic food in East Java. The type of research used in this research is the study of phenomenology. Subjects of research is industries of organic food institution included UMKM for organic food, Department of Agriculture, Food Industry, Organic Food Farmers Group, and Banking in Lumajang District, Malang District and Blitar District in East Java Province. Data collection methods used are indepth interviews and participation observation. Test the validity of data used is the triangulation of sources and methods. The research data were analyzed with qualitative analysis (Content Analysis) by using the interactive model of Miles and Huberman. From the research results, it can be conclude that the pattern of industries institutional development of organic food in East Java divided into three optimize patterns namely the cluster pattern, the pattern of partnerships, and the pattern of BDSP (Business Development Services Provider). The clusters pattern is the industries institutional development of organic food with organic food way of grouping institutions (including UMKM) in a region or set the region as a specific business area. A partnership consisting of the core plasma partnerships and foster father partnerships. BDSP pattern is a pattern based development institution in the system of business development services. In general, the cluster pattern can improve the performance of the supply, distribution, marketing, and utility of industries of organic food in East Java. Lumajang District is the most potential area in the development of cluster patterns industries of oganic food.
\end{abstract}

Key word: organic food, industries institutional development, the clusters pattern, the pattern of partnerships

\section{PENDAHULUAN}

Pangan adalah bahan-bahan yang dimakan sehari-hari untuk memenuhi kebutuhan energi bagi pemeliharaan, pertumbuhan, kerja, dan penggantian jaringan tubuh yang rusak. Ada beberapa permasalahan yang berpengaruh di dalam bidang produksi pangan yaitu: 1) sentra produksi pangan hanya di daerah tertentu, 2) produksi pangan masih tergantung kepada musim, dan 3) produksi pangan bersifat fluktuasi yang dipengaruhi oleh cuaca dan hama penyakit. Penyelesaian permasalahan pangan harus diorientasikan kepada penyediaan pangan nasional (Budiyanto, 2002). Peningkatan penyediaan pangan nasional dimaksudkan untuk mencapai kemandirian pangan nasional dengan indikator terpenuhinya kebutuhan pangan tingkat rumah 
tangga, yang direpresentasikan oleh konsumsi energi sebesar minimal $2.000 \mathrm{kkal} / \mathrm{kap} / \mathrm{hari}$ dan konsumsi protein 52 gram/kap/hari. Dalam upaya mengembangkan kemandirian pangan, maka salah satu hal penting dalam penyediaan pangan nasional adalah penyediaan pangan organik (Deptan RI, 2006).

Menurut Winarno dalam Bahar (2008) konsumen dalam dan luar negeri, khususnya di negara maju, seperti Eropa, Jepang, dan Amerika sangat tertarik terhadap pangan organik dikarenakan motivasi kesehatan, produknya lebih segar, rasanya enak, bagus teksturnya, dan memiliki sifat spesifik yang dapat memberikan kepuasan serta kenikmatan tersendiri. Di beberapa negara maju, pertanian organik telah menunjukkan porsi yang cukup baik dalam sistem produksi pangan. Di Austria 10\% dari berbagai bahan pangan berasal dari pertanian organik, di Swiss pangan organik mencapai 7,8\%, dan di beberapa negara lainnya seperti Amerika Serikat, Perancis, Jepang, dan Singapura, kemajuan dalam pertanian organik mencapai lebih dari $20 \%$ setiap tahunnya.

Salah satu upaya yang perlu dilakukan untuk meningkatkan penyediaan pangan organik adalah dengan terus mengembangkan kelembagaan industri pangan organik (Suleman, 2006). Pengembangan kelembagaan pertanian organik menjadi penting dan strategis karena dapat menjadi lokomotif bagi pengembangan pertanian organik. Berdasarkan hal tersebut di atas, maka penelitian ini didesain untuk mengindentifikasi optimasi pengembangan kelembagaan industri pangan organik di Jawa Timur.

\section{METODE}

Pendekatan penelitian yang digunakan dalam penelitian ini adalah penelitian kualitatif. Jenis penelitian yang digunakan dalam penelitian ini adalah penelitian fenomenologi yang ingin menjelaskan fenomena yang berupa pengalamanpengalaman yang dialami seseorang dalam kehidupannya (Moleong, 1998, Budiyanto, 2002). Penelitian ini ingin menjelaskan fenomena yang berupa pengalaman yang dialami seseorang dalam optimasi pengembangan kelembagaan industri pangan organik di Jawa Timur.

Subyek penelitian yang digunakan dalam penelitian ini adalah lembaga industri pangan oganik yang terdiri dari UMKM pangan organik, Dinas Pertanian, Industri Pangan, Kelompok Tani Pangan Organik, dan Perbankan di Kabupaten Lumajang, Kabupaten Malang, dan Kabupaten Blitar Provinsi Jawa Timur. Sampel penelitian diambil secara
Puposive Sampling. Fokus penelitian yang dikaji dalam penelitian ini adalah optimasi pengembangan kelembagaan industri pangan organik di Jawa Timur. Metode pengumpulan data yang digunakan adalah wawancara mendalam dan observasi peran serta.

Uji keabsahan data yang digunakan dalam penelitian ini adalah triangulasi sumber dan metode. Data penelitian yang diperoleh dianalisis dengan analisis kualitatif (Content Analysis) dengan menggunakan Interactive Model dari Miles dan Huberman (Miles and Huberman, 1994). Model ini mengandung 4 komponen yang saling berkaitan, yaitu (1) pengumpulan data, (2) penyederhanaan atau reduksi data, (3) penyajian data, (4) penarikan dan verifikasi simpulan.

\section{HASIL DAN PEMBAHASAN}

Dari hasil penelitian dapat dinyatakan bahwa optimasi pengembangan kelembagaan industri pangan organik di Jawa Timur terbagi ke dalam tiga pola optimasi yaitu pola klaster, pola kemitraan, dan pola BDSP (Business Development Services Provider). Kelembagan industri pangan organik yang ditemukan dalam penelitian ini adalah Kelompok Tani, UMKM Pangan Organik, dan Industri Pangan Organik. Pola klaster dalam pengembangan kelembagaan industri pangan organik di Jawa Timur merupakan pola pengembangan yang paling banyak ditemukan.

Pola klaster merupakan pengembangan kelembagaan industri pangan organik dengan cara pengelompokkan lembaga pangan organik (termasuk UMKM) dalam suatu kawasan atau menetapkan wilayah sebagai kawasan usaha/industri tertentu yang berdampak kepada pengelompokkan kelembagaan usaha tersebut, dengan demikian memudahkan pembinaan dan pengembangannya. Pola ini mengkaitkan antara input - proses - output dan pasar secara terangkai yang berbasis pada satu jenis komoditas pangan organik tertentu (klaster komoditas) atau pada kelompok usaha atau industri pangan organik tertentu (klaster industri). Peran Pemerintah Daerah dalam pengembangan pola klaster adalah menyiapkan paket kebijakan pengembangan kelembagaan berbasis klaster komoditas atau klaster usaha/industri, pengembangan akses lembaga ke pasar lokal, domestik dan global.

Menurut Tanjung (2009), banyak lembaga usaha mikro, kecil, dan menengah gagal beroperasi karena tidak mendapatkan kepastian terhadap penyediaan input dan pemasaran output. Lembaga keuangan misalnya kurang melihat perspektif mata rantai produksi, pengolahan, pemasaran sebagai suatu rangkaian usaha yang beroperasi secara menyatu dan modal dapat kembali. Disisi lain keterlibatan 
input, proses, output, dan akses pasar pada lembaga usaha sering tidak terorganisir secara benar. Paket kebijakan dalam pengembangan usaha juga sangat sektoral dan tidak terfokus pada satuan kelompok usaha yang terangkai.

Secara umum pola klaster yang diterapkan di Kabupaten Lumajang mampu meningkatkan kinerja penyediaan, distribusi, pemasaran, dan utilitas industri pangan organik di Jawa Timur. Kinerja penyediaan meliputi: ketersediaan lahan, kualitas lahan, sentra produksi, proses produksi, kuantitas produk, kualitas produk, dan diversifikasi produk olahan. Kinerja distribusi dan pemasaran meliputi: akses jalan, sarana angkutan, jaringan transportasi, pasar induk, dan corporate farming. Kinerja utilitas meliputi: pola penggunaan, perdagangan antar provinsi, antar pulau, dan ekspor.

Pola kemitraan dalam pengembangan kelembagaan industri pangan organik banyak ditemukan di Kabupaten Lumajang dan sedikit ditemukan di Kabupaten Malang dan Kabupaten Blitar. Menurut Tanjung (2009), pola kemitraan terdiri dari kemitraan inti plasma dan kemitraan bapak angkat. Kemitraan menurut Peraturan Pemerintah No. 44 Tahun 1997 adalah kerjasama usaha antara usaha kecil dengan usaha menengah dan atau dengan usaha besar disertai pembinaan dan pengembangan oleh usaha menengah dan atau usaha besar dengan memperhatikan prinsip saling memerlukan, saling memperkuat, dan saling menguntungkan.

Kemitraan dalam rangka keterkaitan usaha diselenggarakan melalui pola-pola yang sesuai dengan sifat dan tujuan usaha yang dimitrakan dengan diberikan peluang kemitraan seluas-luasnya kepada usaha kecil, oleh pemerintah dan dunia usaha. Polapola kemitraan yang umum dijumpai antara lain kemitraan inti plasma dan pola bapak angkat. Dalam kegiatan perdagangan pada umumnya, kemitraan antara usaha besar dan atau usaha menengah dengan usaha kecil dapat berlangsung dalam bentuk kerjasama pemasaran, penyediaan lokasi usaha, atau penerimaan pasokan dari usaha kecil mitra usahanya untuk memenuhi kebutuhan yang diperlukan oleh usaha besar dan atau usaha menengah yang bersangkutan. Usaha besar dan usaha menengah yang melaksanakan kemitraan mempunyai hak untuk mengetahui kinerja kemitraan usaha kecil sebagai mitra binaannya. Sementara usaha kecil yang bermitra mempunyai hak untuk memperoleh pembinaan dan pengembangan dari usaha besar dan atau usaha menengah mitranya dalam satu aspek atau lebih tentang pemasaran, sumber daya manusia, permodalan, manajemen, dan teknologi (Tanjung, 2009).
Di Kabupaten Lumajang kemitraan inti plasma terjadi antara Kelompok Tani, UMKM pangan organik dan Industri pangan Organik. PT. Sewu Segar Nusantara, PT. Catur Kirana, dan PT. Star Fruit yang merupakan industri pangan organik telah melakukan pembinaan Kelompok Tani dan UMKM pangan organik. Pembinaan tersebut meliputi: fasilitasi program unggulan Agropolitan Senduro Pasrujambe (SEROJA) yang menjadi program unggulan Pemerintah Daerah Kabupaten Lumajang, teknik budidaya yang ramah lingkungan, SOP Agribisnis, pembibitan, pengolahan, implementasi model manajemen pemasaran corporate farming, dan inovasi serta adopsi teknologi dengan bekerjasama dengan Dinas Pertanian Kabupaten Lumajang, BPTP Provinsi Jawa Timur, dan Balai Besar Mekanisasi Pertanian.

Menurut Tanjung (2009) dalam pola inti plasma, usaha besar dan atau usaha menengah sebagai inti membina dan mengembangkan usaha kecil yang menjadi plasmanya antara lain meliputi: 1) Penyediaan dan penyiapan lahan, 2) Penyediaan sarana produksi, 3) Pemberian bimbingan teknis manajemen usaha dan produksi, 4) Perolehan, penguasaan, dan peningkatan teknologi yang diperlukan, 5) Pembiayaan; dan 6) Pemberian bantuan lainnya yang diperlukan bagi peningkatan efisiensi dan produktivitas usaha. Di sisi lain dalam hal kemitraan usaha besar dan atau usaha menengah dengan usaha kecil berlangsung dalam rangka sub kontrak untuk memproduksi barang dan atau jasa, usaha besar atau usaha menengah memberikan bantuan antara lain berupa: 1) kesempatan untuk mengerjakan sebagian produksi dan atau komponen, 2) kesempatan yang seluas-luasnya dalam memperoleh berbagai bahan baku produksi secara berkesinambungan dengan jumlah dan harga yang wajar, 3) bimbingan dan kemampuan teknis produksi atau manajemen, 4) perolehan, penguasaan, dan peningkatan teknologi yang diperlukan, dan 5) pembiayaan. Pola kemitraan inti plasma ini dimaksudkan tidak saja untuk mengembangkan UMKM tetapi juga sebagai upaya semakin memantapkan pertanggungjawaban sosial Usaha Besar dan Menengah.

Pola BDSP (Business Development Services Provider) merupakan pengembangan kelembagaan industri pangan organik berbasis pada sistem lembaga jasa pengembangan usaha. Di Kabupaten Lumajang, Kabupaten Malang, dan Kabupaten Blitar sudah ada pola pengembangan kelembagaan industri pangan organik secara BDSP tetapi belum berkembang secara optimal. Beberapa Lembaga Pengabdian kepada Masyarakat Perguruan Tinggi dan LSM telah ikut mensosialisasikan program SPFS (Special Program for Food Security) yang 
merupakan program khusus ketahanan pangan yang diselenggarakan oleh FAO di Indonesia kepada lembaga-lembaga pangan organik yaitu Kelompok Tani dan UMKM pangan organik.

Menurut Tanjung (2009) BDSD adalah suatu lembaga yang mempunyai kegiatan dalam bentukjasa dalam berbagai bidang yang dilakukan oleh individu dan atau lembaga untuk tujuan pengembangan usaha, dalam hal ini UMKM. Kementerian Koperasi dan UKM mendefinisikan BDSP sebagai lembaga atau bagian dari lembaga yang memberikan layanan pengembangan bisnis dalam rangka meningkatkan kinerja UMKM. Lembaga tersebut berbadan hukum, bukan lembaga keuangan, serta dapat memperoleh fee dari jasa layanannya. Peningkatan jasa-jasa strategis mempunyai nilai khusus bagi peningkatan kinerja UMKM di kebanyakan negara berkembang. BDSP dapat berasal dari lembaga teknis di Departemen Pertanian (BPP PPL), Departemen Koperasi dan UKM (BDS), Departemen Perindag dan Lembaga Bank, tetapi juga dapat berasal dari lembaga swasta, misalnya: 1) Konsultan seperti yang tergabung dalam Inkindo, Iwapi, Kadin, Asosiasi BDS, Swiss Contact dan konsultan swasta lainnya, 2) LPSM Konsultan/Pendamping Sosial, seperti Bina Swadaya, LP3ES, Altrabaku dan lain-lain, dan 3) Lembaga Penelitian, Lembaga Pengabdian kepada Masyarakat, Lembaga Konsultan/Pendamping seperti yang dibentuk oleh Perguruan Tinggi Negeri dan Swasta. Semua lembaga tersebut secara sinergis diharapkan mampu menjadi Services Provider dalam upaya pengembangan UMKM.

Salah satu BDSP dari lembaga teknis pemerintah yang intensif melakukan pengembangan Kelompok Tani dan UMKM pangan organik di Kabupaten Lumajang adalah Balai Pengkajian Teknologi Pertanian (BPTP) Provinsi Jawa Timur dan Balai Besar Mekanisasi Pertanian Departemen Pertanian yang telah banyak berperan dalam inovasi dan adopsi teknologi. BPTP Provinsi Jawa Timur juga mendampingi Kelompok Tani dan UMKM pangan organik untuk melakukan perbaikan teknologi budidaya sesuai SPO, mulai dari penggunaan bibit berkualitas, cara tanam, dan pemupukan dalam upaya meningkatkan produktivitas dan kualitas hasil pangan organik. BPTP Provinsi Jawa Timur juga berperan dalam pengembangan pilot projecting, permodalan, pendampingan, dan penguatan sistem produksi, distribusi, pemasaran, dan konsumsi.

Lembaga Bank di Kabupaten Lumajang, Kabupaten Malang, dan Kabupaten Blitar juga berperan sebagai BDSP dengan melakukan pengembangan Kelompok Tani dan UMKM pangan organik melalui penyaluran pinjaman modal dengan pola penyaluran pinjaman ke Kelompok Tani dan ke Gapoktan sebagai lembaga penjamin. Menurut Tanjung (2009), ada tiga pola penyaluran pinjaman modal yaitu: 1) Bank melakukan pelayanan keuangan langsung kepada kelompok yang sudah dibentuk dan dibina oleh koordinator kelompok. Bank dan koordinator kelompok melakukan koordinasi dalam penyaluran dan pengembalian kredit, 2) Bank memberikan pelayanan keuangan kepada kelompok melalui Lembaga Penjamin (LP). Biaya kegiatan pembinaan diperoleh LP selisih bunga kredit dari bank dengan yang dibayar oleh kelompok. Akad kredit dilakukan antara bank dengan Pimpinan LP yang memiliki kewenangan legal. Kemudian akad kredit antara pimpinan LP dengan Ketua atau Pengurus kelompok yang memperoleh kuasa dari para anggotanya atau atas dasar keputusan rapat anggota yang dibuktikan oleh dokumen berita acara atau notulen dalam hubungan ini LP bertindak sebagai executing agent, dan 3) Bank mengidentifikasi sendiri kelompok yang telah ada, atau memfasilitasi proses pembentukan kelompok di antara pengusaha mikro potensial yang sudah terseleksi, memberikan pelayanan keuangan dan sekaligus membina kelompok-kelompok tersebut sebagai nasabahnya. Akad kredit dilakukan antara bank dengan ketua atau pengurus kelompok yang memperoleh kuasa dari para anggotanya atau atas dasar keputusan rapat.

Kabupaten Lumajang merupakan daerah yang paling potensial dalam pengembangan pola klaster industri pangan oganik dibandingkan dengan Kabupaten Malang dan Kabupaten Blitar. Peran Pemerintah Daerah Kabupaten Lumajang dalam pengembangan kelembagaan industri pangan organik diantaranya adalah: 1) Menciptakan peluang pasar lokal, domestik dan global sebagai respon terhadap perkembangan yang ada, 2) Melakukan terbosan-terobosan dalam pengembangan teknologi sistem produksi, pengolahan, dan pemasaran, 3) Menguatkan dan mengaktifkan jalinan hubungan secara kemitraan antar pelaku dalam proses produksi, pengolahan, dan pemasaran, 4) Melakukan identifikasi sumberdaya yang potensial secara lebih intensif, 5) Menciptakan produk yang memiliki keunggulan komparatif, dan 6) Memanfaatkan sumber daya yang tersedia guna memperoleh nilai tambah yang lebih tinggi. Peran-peran tersebut mampu menjadikan pengembangan kelembagaan pangan oganik pola klaster berjalan dan berkembang dengan baik.

Salah satu terobosan yang dilakukan oleh Pemerintah Daerah Kabupaten Lumajang dalam pengembangan kelembagaan pangan organik adalah menetapkan kawasan agropolitan pangan organik. Terobosan tersebut dilakukan dengan menetapkan 
Desa Burno, Kecamatan Senduro, Kabupaten Lumajang sebagai kawasan agropolitan pisang yang berdampak kepada pertumbuhan ekonomi. Menurut Anugrah (2003) penetapan kawasan agropolitan akan berdampak kepada pertumbuhan ekonomi kawasan.

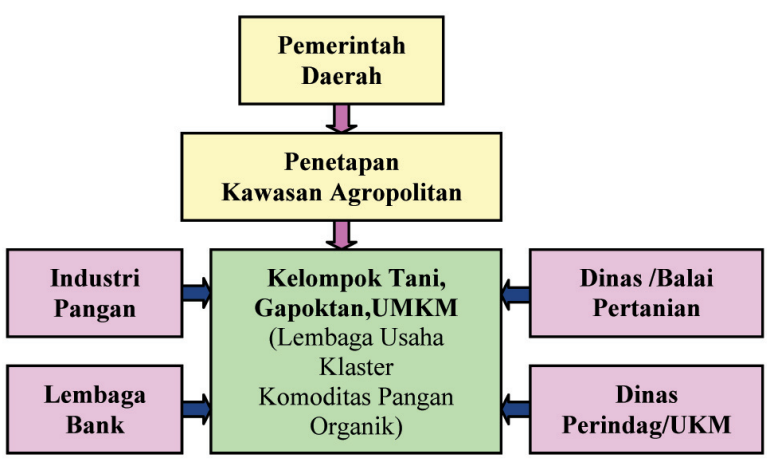

Gambar 1. Optimasi Pengembangan Kelembagaan Industri Pangan Organik Berbasis Pola Klaster di Kabupaten Lumajang

Dalam kawasan agropolitan yang ditetapkan oleh Pemerintah Daerah Lumajang juga dibuat cooperative farming yang akan digunakan sebagai fasilitas dalam pengembangan kelembagaan industri pangan organik. Menurut Nuryanti (2005) melalui cooperative farming dapat dilakukan rekayasa sosial, ekonomi, teknologi, dan nilai tambah. Rekayasa sosial dapat dilakukan dengan cara penguatan kelembagaan petani, penyuluhan, dan pengembangan SDM, sedangkan rekayasa ekonomi dilakukan dengan pengembangan akses permodalan untuk pengadaan sarana prasarana produksi dan akses pasar.

Kelompok Tani sebagai salah satu kelembangaan pangan organik juga dikembangkan dengan baik di Kabupaten Lumajang maupun di Kabupaten Malang dan Kabupaten Blitar. Pengembangan kelembagaan Kelompok Tani terdiri atas: 1) Penguatan managerial kelompok, 2) Peningkatan knowledge-skills, penguasaan sistem usaha produksi - distribusi - pemasaran - konsumsi, 3) Pengembangan pusat informasi petani, dan 4) Pengembangan semua supproting system (hardware, software, brainware, fund, networking). Dalam upaya mempermudah pengembangan kelembagaan Kelompok Tani, maka lembaga itu diikat dalam Gabungan Kelompok Tani (Gapoktan). Gapoktan inilah yang menjadi lokomotor dan koordinator peningkatan produksi dan pemasaran. Menurut Warsana (2009) dan Wahyuni (2009) dalam Gapoktan dilakukan usaha agribisnis dalam upaya mencapai peningkatan produksi dan pendapatan usaha tani.

Pengembagan kelembagaan Kelompok Tani dan UMKM pangan organik di Kabupaten Lumajang dan Kabupaten Blitar juga dalam hal inovasi dan adopsi teknologi agribismis dan pengolahan hasil pangan organik. Menurut Rafieq (2003) dan Warsana (2008) teknologi sederhana yang applicable potensial untuk dikembangkan dalam inovasi teknologi yang biasanya justru tepat sasaran. Menurut Hendayana (2008) salah satu faktor percepatan adopsi inovasi teknologi itu adalah tersedianya dana sebagai modal pasca adopsi teknologi yang dapat dilakukan melalui penyuluhan.

Pengembangan kelembagaan industri pangan organik di Kabupaten Lumajang secara umum dilakukan dalam upaya menciptakan atmosfer usaha yang kondusif. PT. Sewu Segar Nusantara, PT Catur Kirana, dan PT. Star Fruit, telah mampu merubah pola usaha tani pangan organik dari cara bertanam ala kadarnya menjadi menerapkan sistem agribisnis pangan organik yang diikuti inovasi teknologi anjuran (SOP = Standard Operasional Prosedure). Suatu kajian di Desa Pasrujambe Kecamatan Pasrujambe (lokasi Prima Tani Kabupaten Lumajang) menunjukkan adanya perbaikan teknologi budidaya sesuai SOP, mulai dari penggunaan bibit berkualitas, cara tanam dan pemupukan, dan telah mampu meningkatkan produktivitas dan kualitas hasil pangan organik.

Di Kabupaten Lumajang, Kabupaten Malang, dan Kabupaten Blitar, Lembaga Bank juga berperan sebagai dalam pengembangan Kelompok Tani dan UMKM pangan organik melalui penyaluran kredit. Menurut Sutrisno (2009) dan Badan Pusat Statistik (2004) di bidang jasa keuangan pada saat ini lembaga perbankan telah menciptakan berbagai produk perkreditan dan pembiayaan yang tersedia untuk UKM. Kredit mikro sudah menjadi industri keuangan baru yang dibuka untuk persaingan secara luas tanpa proteksi khusus yang juga diikuti dukungan secara selektif untuk sektor tertentu dengan jaminan dan subsidi pemerintah melalui APBN dan APBD. Respon berbagai pihak terkait dalam optimasi pengembangan kelembagaan industri pangan organik di Jawa Timur menunjukkan bahwa optimasi pola klaster merupakan pola optimasi pengembangan yang paling tepat, sebagaimana disajikan pada Gambar 2.

Secara umum optimasi pola klaster memiliki keunggulan dan prospektif untuk mengembangkan kelembagaan industri pangan organik di satu sisi dan akan meningkatkan nilai ekonomis di sisi yang lain. Menurut Sutrisno (2009) pendekatan klaster disamping dapat memudahkan pengembangan lembaga usaha/industri tetapi juga dapat digunakan untuk membangun industri jasa perusahaan yang kuat. Dalam upaya memajukan UKM dalam jangka panjang, pemerintah daerah perlu membangun 


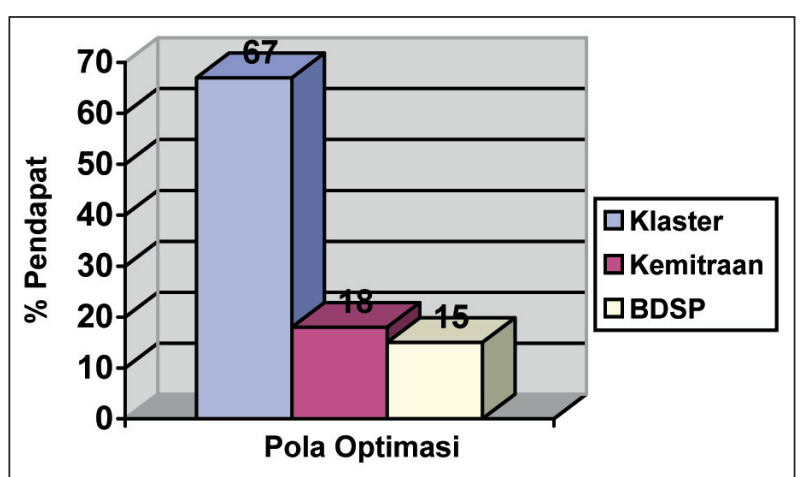

Gambar 2. Persentase Jajak Pendapat

infrastruktur (fisik) untuk membangun klaster industri jasa perusahaan di tempat yang strategis yang akan menjadi pusat pelayanan pengembangan usaha melalui pasar dan tumbuh dalam satu lokasi yang kompak sebagai bagian dari city supporting services. Badan Layanan Umum Jasa Layanan Pengembangan Usaha (BLU-JLPU) Kementerian Koperasi dan UKM menjadi lokomotif pengembangan klaster sebagai dasar pendukung pengembangan klaster UKM di daerah. Fokus ini akan menjadi perjuangan strategis pengiat pengembangan UKM di daerah, sejalan dengan fakta investasi swasta dan masyarakat mencapai porsi terbesar $70-80 \%$ dari investasi nasional/daerah.

Pengalaman pertumbuhan pendekatan klaster industri di Asia menunjukkan bahwa penggunaan pendekatan klaster memiliki kinerja signifikan dalam pertumbuhan usaha/industri. Industrialisasi di Asia Timur memang menjadi patron Indonesia karena Jepang sebagai negara industri tertua di Asia merupakan negara industri yang memiliki tradisi industri kecil menengah yang kuat dengan orientasi ekspor serta memiliki tradisi industri kerajinan yang kuat. Model OVOV (One Village One Product) adalah model orisinil Jepang. Jepang mengembangkan industri kecil dengan intervensi yang jelas, kuat dan konsisten. Sementara Taiwan, Hongkong dan Korea tumbuh dengan patron yang berbeda-beda satu sama lain. Taiwan mengembangkan UKM dengan melalui dukungan pusat inkubasi yang kuat dan jumlahnya memadai dan klaster UKM-pun tumbuh dengan baik. Corak perpaduan antara perencanaan dan pasar dijaga baik. Demikian juga pola yang dikembangkan oleh Korea Selatan lebih bertumpu pada pola pengembangan oleh lembaga khusus yang dimiliki pemerintah tetapi mempunyai karakter seperti lembaga bisnis biasa.

Thailand pada masa Pemerintahan Thaksin membawa dua kebijakan terkenal dalam pengembangan ekonomi di akar rumput yaitu pertama formalisasi usaha informal dan adopsi
OTOP (One Thambun One Product) yang mengikuti pola Jepang tetapi dengan kesatuan ekonomi lebih besar, wilayah Thambun setara dengan Kecamatan. Perjalanan China memang unik, karena sebagai Negara dengan perencanaan terpusat mempunyai pola industrialisasi yang khas. Secara eksplisit klaster sebagai pendekatan pengembangan industri di China tidak mengemuka, namun yang jelas pada awal program pembangunan ekonomi pendekatan Township Enterprise (TE) sebagai dan Village Enterprise (VE) atau TVE untuk pola perencanaan oleh Negara (TVE) dan Private Enterprise (PE) yang berkembang dari usaha perorangan dan swasta yang kemudian tumbuh menjadi besar. China mengembangkan industri, terutama peralatan rumah tangga dan pertanian sudah berkembang sejak lama, sebagai ilustrasi Indonesia mengenal produk China sejak tahun 1960an (Kimura, 2007, Sutrisno, 2009, UNCTAD, 2005).

Klaster sebagai pendekatan terbukti semakin diterima dalam pendekatan pembangunan yang melibatkan pola pengelompokan, baik industri maupun infrastruktur, sehingga hakekat klaster akan semakin digunakan. Dengan otonomi daerah, pembangunan perkotaan akan menempati tempat sentral dalam pembangunan daerah, implikasinya pembangunan tempat usaha adalah komponen penting dari kehidupan ekonomi perkotaan di daerah. Oleh karena itu pendekatan klaster pasti akan menjadi bagian pengembangan model di masingmasing daerah. Persoalannya adalah aglomerasi yang optimal harus menghasilkan sinergi untuk efisiensi dan kemajuan berkelanjutan untuk daya saing, (succesfull cluster brought efficiency and sustain progess for better competitive strength). Advokasi klaster pada dasarnya dapat dimulai pada berbagai level baik promosi maupun proteksi, dalam kontek promosi kita sudah banyak belajar dari dunia dan pengalaman kita sendiri yang pada umumnya terjadi pada pengembangan usaha di sektor industri (Lutfansyah, 2006, Shujiro, 2008).

Klaster untuk proteksi mungkin jarang dipikirkan dan dianggap tidak berguna karena dinilai mundur, tetapi dalam suasana ekonomi dualistik seperti kebanyakan negara berkembang dan perkotaan untuk pertimbangan mencegah banyaknya dampak negatif ketimpangan patut dipertimbangkan. Bentuk klaster proteksi misalnya adalah isu pasar tradisional versus pasar modern, penanganan ekonomi kawasan kumuh dan lain-lain yang memerlukan pendekatan berkelompok, menyatu, aglomerasi yang membesar dan menguat, terpadu, layak, sehat, dan aman. Dalam upaya menggerakkan kembali kesadaran akan pentingnya pengembangan klaster bagi UKM di Indonesia menghadapi meningkatnya intensitas 
desentralisasi, maka langkah terbaik adalah mendorong setiap pemerintah kota atau kabupaten membangun miniatur klaster dalam bentuk infrastruktur pusat pelayanan jasa perusahaan. Suatu lokasi dengan infrastruktur memadai di mana semua jenis layanan jasa perusahaan berada di situ dengan sedikit sentuhan layanan perbankan dan finansial lainya akan menjadi pusat pengembangan UKM yang digerakkan oleh pasar. Pelayanan perbankan menjadi penting dan strategis untuk mengembangkan kapital modal UMKM (Sutrisno, 2009, Soetrisno, 2005, Anonymous, 2009).

Dengan berkembangnya pengalaman pembangunan industri kecil dan menengah serta UKM di berbagai negara yang demikian beragam serta menunjukkan klaster kegiatan bisnis adalah kebutuhan, maka klaster akan semakin mendapatkan dasar yang kuat sebagai pendekatan. Lahirnya commercial center di kota besar sebenarnya secara tidak disadari juga mengilhami pola baru penyatuan layanan bisnis karena kita dapat belanja informasi pengembangan usaha dan jasa-jasa yang diperlukan di tempat itu. Perkembangan baru ini akan semakin memperkuat alasan penggunaan pendekatan klaster dalam pengembangan UMKM di tanah air (Sutrisno, 2009).

\section{SIMPULAN}

Berdasarkan hasil penelitian, maka dapat ditarik kesimpulan penelitian yaitu sebagai berikut: 1) optimasi pengembangan kelembagaan industri pangan organik di Jawa Timur terbagi ke dalam tiga pola optimasi yaitu pola klaster, pola kemitraan, dan pola BDSP (Business Development Services Provider). Pola klaster merupakan optimasi pengembangan kelembagaan industri pangan organik dengan cara pengelompokan lembaga industri pangan organik (termasuk UMKM) dalam suatu kawasan atau menetapkan wilayah sebagai kawasan usaha/ industri pangan tertentu. Pola kemitraan terdiri dari kemitraan inti plasma dan kemitraan bapak angkat. Pola BDSP merupakan pola pengembangan berbasis pada sistem lembaga jasa pengembangan usaha, 2) Secara umum pola klaster mampu meningkatkan kinerja penyediaan, distribusi, pemasaran, dan utilitas industri pangan organik di Jawa Timur. Kabupaten Lumajang merupakan daerah yang paling potensial dalam pengembangan pola klaster industri pangan oganik.

\section{DAFTAR PUSTAKA}

Anugrah, I.S., 2003. Kunci-Kunci Keberhasilan Pengembangan Agropolitan, Bogor: Puslitbang Sosial Ekonomi Pertanian Bogor, Tabloid Sinar Tani, 17 Maret 2003.
Anonymous, 2009. Catatan Agenda Pengembangan UMKM ke Depan, Koran Bisnis Indonesia, Jakarta, Juni, 2009.

Badan Pusat Statistik, 2004. Pengkajian Dukungan Finansial dan Non Finansial dalam Pengembangan Sentra Bisnis Usaha Kecil dan Menengah, Kerjasama Kementerian Koperasi dan UKM-BPS, Jakarta; BPS.

Bahar, Y.H., 2008. Pertanian Organik, ataukah Pertanian Berkelanjutan, http://www. hortikultura.deptan.go.id, Diakses 14 Januari 2009.

Budiyanto, M.A.K, 2002. Dasar-dasar Ilmu Gizi,. Malang: UMM Press..

Budiyanto, M.A.K., 2002. Metodologi Penelitian. Malang: Universitas Muhammadiyah. Malang.

Deptan RI, 2006. Revitalisasi Pertanian. Http://agribisnis. deptan.go.id, 1 Januari 2007).

Hendayana, R., 2008. Membangun Lembaga Keuangan Mikro Berbasis Komunitas Petani, Bogor: Balai Besar Pengkajian dan Pengembangan Teknologi Pertanian (BBP2TP), Sinar Tani, 2 September 2008.

Kimura, F., 2007. Development Strategies for Economies Under Globalization: Southeast Asia as New Development, dalam New Asian Regionalism Response to Globalisation and Crises, Tran Van Hoa and Charles Harvie (Editor), Palgrave: MacMilan.

Lutfansyah, 2006. Strategi Penguatan Klaster UKM Melalui Pendekatan Klaster Bisnis, Surabaya: Mediatama

Miles, M.B, Huberman, A.M, 1994. Qualitative Data Analysis, Second edition, Sage Publication, New Delhi.

Moleong, L.J., 1998. Metode Penelitian Kualitatif. Bandung: Remaja Rosdakarya.

Nuryanti, S., 2005. Cooperative Farming untuk Peningkatan Pendapatan Petani, Bogor: Pusat Penelitian dan Pengembangan Sosial Ekonomi Pertanian Bogor, Tabloid Sinar Tani, 29 Juni-5 juli 2005.

Rafieq, A., 2003. Mengembangkan Pengetahuan Petani untuk Inovasi Teknologi. Kalimantan Selatan: BPTP Kalsel, Tabloid Sinar Tani, 14 Mei 2003.

Shujiro, U., 2008. Policy Recommendation for SME Promotion in the Republic of Indonesia, Jakarta: JICA.

Suleman, A., Prihandarini, R., dan Sudjais, Z. 2006. Menghantarkan Indonesia Menjadi Produsen Organik Terkemuka. Proceeding MAPORINA

Soetrisno, N., 2009. Pengembangan Klaster IKM/UKM di Indonesisa: Pengalaman dan Prospek. http:// fornaslpumkm.wordpress.com, Diakses 05 Pebruari 2009.

Soetrisno, N., 2005. Kebijakan Pengembangan Usaha Kecil dan Menengah di Indonesia, Makalah Seminar Nasional ISEI, ISEI, Malang.

Tanjung, D.E., 2009. Pola Pendekatan Pemberdayaan UMKM, http://usaha-umkm.blog.com, Diakses tanggal 23 Januari 2009. 
United Nation Trade and Development, 2005. Improving the Competitiveness of SMEs in Developing Countries, The Role of Finance to Enterprise Development, Geneve: UNCTAD,

Wahyuni, S., 2009. Integrasi Kelembagaan di Tingkat Petani: Optimalisasi Kinerja Pembangunan Pertanian, Bogor: Pusat Analisis Sosial Ekonomi dan Kebijakan Pertanian, Tabloid Sinar Tani, 10 Juni 2009.

Warsana, S.P., 2008. Strategi Melakukan Penyuluhan Pertanian untuk Petani Kecil, Jawa Tengah: BPTP Jawa Tengah, Tabloid Sinar Tani, 9 Januari 2008.

Warsana, S.P/, 2009. Pemantapan Kelembagaan pada Gapoktan, Jawa Tengah: BPTP Jawa Tengah, Tabloid Sinar Tani, 8 April 2009. 